\title{
A Comparative Analysis for the Accounting Reporting of 'Employee Benefits' Between IFRS and Other Accounting Standards: A Case Study for the Biggest Listed Entities in Greece
}

\author{
${ }^{1}$ Konstantinos J. Liapis and ${ }^{2}$ EI Thalassinos \\ ${ }^{1}$ Department of Economics and Regional Development, \\ Accounting and Business Administration, Panteion University, Athens, Greece \\ ${ }^{2}$ Department of Maritime Studies, University of Piraeus, Piraeus, Greece
}

Received 2014-02-07; Revised 2014-03-17; Accepted 2014-06-24

\begin{abstract}
The main aim of this study is to illustrate a comparative analysis for the accounting reporting of "employee benefits" between the International Financial Reporting Standards (IFRS) and other accounting reporting standards. The empirical analysis is carried out in accordance with the Greek Generally Accepted Accounting Principles (GGAAP), with IFRS, following the implementation of International Accounting Standard (IAS) 19 "Employee Benefits" and with the U.S. Financial Accounting Standards (USFAS) 87. The sample consists of the 20 biggest listed entities in the Athens Stock Exchange (FTSE 20 index of the ASE). The contribution of the paper is to review the accounting reporting between different accounting standards, to a great extent, in order to find out the appropriate adjustments that have to be made for the treatment and presentation of employee benefits in the financial statements. The conclusions of the paper would be contributed to debate for the recognition of employee benefits on entities' ac-counting statements in a more accurate way.
\end{abstract}

Keywords: Employee Benefits, IFRS, Accounting Reporting Standards

\section{INTRODUCTION}

The full implementation of the International Accounting Standards (IAS) was imposed in Greece in 2002 and 2003 (Laws 2992/2002 and 3229/2003). The first published financial statements under International Financial Reporting Standards (IFRS) in Greece covers the financial year 2004. According to Law $2992 / 2002$, the IAS applied in the preparation of published financial statements, includes Balance Sheet, Income Statement, Statement of Changes in Equity, Cash Flows and Notes. Entities that have adopted IFRS have to prepare interim financial statements on a quarterly basis similar to the annual ones. The IAS is mandatory for entities which their shares are listed in the Athens Stock Exchange (ASE) and optionally for the other entities, which are audited by an auditor from the Institute of Certified Public Accountants. In relation to Greek General Accepted Accounting Principles (Greek GAAPs) the IFRS require a more detailed accounting information to be published, such as report of the used accounting policies by entity, policies to address various accounting issues providing a detailed analysis of all elements of the Balance Sheet and Profit and Loss Account of a entity in the form of notes report.

The present article is based on the works of Barlev and Haddad (2003), Lange and Howieson (2006), Jean-François (2009), Gerald (1994), Hallman and Rosenbloom (1986), Marsh and Kleiner (2004), Pegg (2009), Reiter and Omer (1992), Severinson (2010), Sutton (1993) and Tarca (2004). All official publications for accounting boards and authorities of IAS, US GAAP and Greek GAAP and instructions from audit agencies are also taken into consideration.

Corresponding Author: Konstantinos J. Liapis, Department of Economics and Regional Development, Accounting and Business Administration, Panteion University, Athens, Greece 
The article focuses on the presentation of the various "employee benefits" as reported in the financial statements after the application of IFRS and especially after the implementation of IAS 19 "employee benefits". It consists of three parts: The first part analyzes the various "employee benefits" and benefit plans in accordance with the international practice and the IFRS. The question to be answered is in what extend "employee benefits" are presented in accounting statements for services, programs or agencies and how the entity covers and demonstrates those benefits for employees.

The second part analyzes similarities and differences between the accounting standards for "employee benefits". The article carries out a comparative analysis between the two main accounting standards, the International Accounting Standards (IAS), or the International Financial Reporting Standards (IFRS) with the U.S GAAPs.

The third part presents the results from the application of IFRS in Greece and especially the issues arising from the establishment of IAS 19. It is a special case of a comparative analysis before and after the application of IFRS in Greece using original data from 20 of the biggest entities listed in the Athens Stock Exchange (FTSE 20).

The article produces useful conclusions with respect to how entities report and how recognize the various kinds of "employee benefits" on their accounting statements. It also presents the differences between accounting standards and trends of changes, shows the key findings in relation to how they have been implemented in Greece with some future developments on the subject as a useful tool to face the recent financial crisis.

\section{THE INTERNATIONAL PRACTICE, IDENTIFICATION AND REPORTING OF "EMPLOYEE BENEFITS" AND "EM- PLOYEE BENEFIT PLANS"}

The international practice and the identification of "employee benefits" by entities differ on the main and basic features according to applicable accounting standards. In this part a detailed presentation of the international practice based mainly on IFRS will be made in an attempt to point out its main characteristics.

\subsection{IFRS and IAS 19}

IAS 19 was adopted by the Council of International Accounting Standards Board in February 1998 and the most recent amendment was made in the summer of 2011. This Accounting Standard describes the financial accounting procedure and how employers should report on their financial statements the obligations towards the "employee benefits". This standard procedure applied by an employer in accounting for all "employee benefits", except those to which IFRS 2 Share-based Payment applies (like stock option plans). The Council of International Accounting Standards issued the IFRS 2 to cover all these programs (A guide through International Financial Reporting Standards (IFRSs) in 2007 issued by the International Accounting Standard Board IASCInternational Financial Reporting Standard 2 "Sharebased Payments" pp. 135-170).

The objective of IAS 19 is to prescribe the accounting obligation and disclosure for the "employee benefits". The Standard requires the entity to recognize:

- A liability when an employee has provided service in exchange for "employee benefits" to be paid in the future; and

- An expense when the entity consumes the economic benefit arising from service provided by an employee in exchange for the "employee benefits

Employee benefits" are benefits in any form received by the employee for his services to an entity. These benefits are reported by the "Funds for Employees" and they are divided into direct payments to employees through P\&L account or into provisions for employee benefit plans after retirement which are further divided into a defined contribution or defined benefit plans. Liabilities and expenses for the entities in connection with "employee benefits" arising from commitments made by employers:

- According to Legislation or

- Following of Ethics

It is a noteworthy recognition of moral commitment of employers over employees under the IAS, for the employee benefit plans which, when they have been identified even indirectly, involve financial costs for the employers.

\subsection{The Types of "Employee Benefits (IAS 19, pp. 1097-1106, IN2, Paragraph 7)}

Employee benefits" are all forms of consideration given by an entity in exchange for a service rendered by employees. The employee benefits are divided into several categories as follows:

\subsubsection{Immediate or Short-Term "Employee Benefits}

Short-term employee benefits are "employee benefits" (other than termination benefits) which fall due 
wholly within twelve months after the end of the period in which the employees render the related service. When an employee has rendered service to an entity during an ac-counting period, the entity shall recognize the undiscounted amount of short-term "employee benefits" expected to be paid in exchange for that service:

- As a liability (accrued expense), after deducting any amount already paid. If the amount already paid exceeds the undiscounted amount of the benefits, the entity shall recognize that excess as an asset (prepaid expense) to the extent that the prepayment will lead to, for example, a reduction in future payments or a cash refund

- As an expense, unless another Standard requires or permits the inclusion of the benefit in the cost of an as-set (see, for example, IAS 2 Inventories and IAS 16 Property, Plant and Equipment)

These benefits are divided into:

- Financial benefits such as:

- Wages and salaries

- Social security contributions

- Benefits or compensations such as holiday paysickness

- Additional remuneration to staff (bonuses, other benefits)

- Non-financial benefits such as:

- Services provided by entity to employees that is:

- Health care

- Nurseries expenses

- Educational programs

- Non cash benefits by entity to employees like:

- Car and car expenses, mobile phone and expenses

- Clothing, catering, housing, accommodation

\subsubsection{Employee Benefits" After Retirement}

Post-employment benefits are "employee benefits" (other than termination benefits) which are payable after the completion of employment. Post-employment benefit plans are formal or informal arrangements under which the entity provides post-employment benefits for one or more employees. Post-employment benefit plans are classified as either defined contribution plans or defined benefit plans, depending on the economic sub-stance of the plan as derived from its principal terms and conditions.

These benefits are divided into:

- Pensions

- Lump sum pension payments. These benefits may be covered by relevant laws or internal commitments agreed between employer-employee
- Insurance employees after retirement such as:

- Life insurance

- Sickness insurance

\subsubsection{Other Long Term Benefits for Employees}

Other long-term benefits are "employee benefits" (other than post-employment benefits and termination benefits) which do not fall due wholly within twelve months after the end of the period in which the employees render the related service. The Standard requires a simpler method of accounting for other longterm "employee benefits" than for post-employment benefits. Actuarial gains and losses and past service cost are recognized immediately.

These benefits are divided into:

- Accidents, damages, extra licenses

- Disability benefits

- Facilities through a profit distribution for a service period more than 12 months

\subsubsection{Termination Benefits}

Termination benefits are "employee benefits" payable as a result of either:

- An entity's decision to terminate an employee's employment before the normal retirement date

- An employee's decision to accept voluntary redundancy in exchange for those benefits

The entity recognizes termination benefits as a liability and an expense when and only when, the entity is demonstrably committed to either:

- Terminate the employment of an employee or group of employees before the normal retirement date

- Provide termination benefits as a result of an offer made in order to encourage voluntary redundancy

where, termination benefits fall due more than 12 months after the balance sheet date, they shall be discounted. In the case of an offer made to encourage voluntary redundancy, the measurement of termination benefits shall be based on the number of employees expected to accept the offer.

These allowances are given to employees when they cease to work, not because of the completion of pensionable age, but with the decision of the employer or exhortation. The entity recognizes compensation benefits due to retirement as a liability and an expense when and only when, the entity is demonstrably committed to why such claims are covered by labor laws or internal regulations-organizations of entity. These are typically arising from: 
- Redundancy

- Compensation voluntary retirement

Occasionally entities, worldwide, provide incentives through early retirement plans to their employees to leave the work voluntarily, usually after direct monetary consideration, which may be accompanied by other benefits. The programs are mostly voluntary retirement plans in order to avoid the provisions of labor protection laws in the case of "Redundancy".

\subsection{Employee Benefits Plans, Vehicles and Providers}

For the coverage of "employee benefits" several programs are usually created. These programs are recognized by the IAS either morally or legally. They may have the forms:

\subsubsection{Benefit Programs Legally Recognize by the Entity}

These programs are easily recognizable and usually arise:

Through organizations such as:

- Insurance funds or entities under:

- Public law

- Private law

- Insurance programs

- Professional funds

- Cash or investment accounts

Through contracts such as:

- Commitments of employer-employee

- Provisions by internal regulations

- Insurance and workers rights

\subsubsection{Benefit Programs for Which the Entity Morally Bound}

These programs are not easily recognizable but usually occur when:

- The "employee benefit" has a customary character (always covered by the entity, but it has no obligation to pay)

- The "employee benefit" not covered by the entity or other body and in this case the entity should cover it.

- The obligator is unable to cover the burden of employee and employees are directed to the entity. In this case the entity will either recognize the ethical provision under IAS 19 or under IAS 37 as a "contingent liability (A guide through International Financial Reporting Standards (IFRSs) in 2007 issued by the International Accounting Standard Board IASC-International Ac-counting Standard 37 "Provisions, Contingent Liabilities, Contingent Assets Share-based Payments" pp. 1693-1728)

\subsection{Coverage of "Employee Benefits" Through Employee Benefit Plans}

The coverage of "employee benefits" through employee benefit plans by the entity under provisions of IAS 19 may occur in three different ways:

\subsubsection{The "Employee Benefits" are Immediately Recognized as a Liability and an Expense for the Entity in the form of Cash Payments to Employees}

When an employee has provided service and especially in the case of the direct, short-term benefits to the entity during an accounting period, the entity will recognize the undiscounted amount of short-term "employee benefits" expected to be paid in exchange for that service. The accounting procedure is done by identifying.

A liability (accrued expense), after deducting any amount already paid. If the amount already paid exceeds the undiscounted amount of benefits, the entity shall recognize the excess as an asset (prepaid expense) to the extent that the prepayment will lead to a reduction in future payments or a cash refund from the employee.

An expense, unless another standard requires or permits to perform work included in the cost of an asset (direct labor participation in stock value through product costing IAS 2 Inventories and same-produced fixed bindings and general expenses if al-lowed, IAS 16 Property, Plant and Equipment). If the supply of goods by entity to employees that are as-sets of the entity (car, mobile) that assigns employees to use while recognizing the expense of the depreciation. For other non-standard goods (clothing, restaurants, rental housing) the expense is recognized by the entity and the benefit of the consumer reap the workers. The fees through distribution of profits have been often recognized by the tax or corporate law as a rule and if the supply of goods IFRSs require transport to the cost of staff wages, due to the absence of other provisions in other articles.

\subsubsection{With Payment of Dues or Contributions and Recognition as an Expense Without Any Further Obligation}

Defined contribution plans are post-employment benefit plans under which the entity pays fixed contributions into a separate entity (for example a fund) 
having no legal or constructive obligation to pay further contributions if the fund does not hold sufficient assets to pay all "employee benefits" relating to employee's service in the current and prior periods. Under defined contribution plans.

The entity's legal or constructive obligation is limited to the amount that it agrees to contribute to the fund. Thus, the amount of the post-employment benefits received by the employee is determined by the amount of contributions paid by the entity (and per-haps also the employee) to a post-employment benefit plan or to an insurance entity, together with in-vestment returns arising from the contributions.

The actuarial risk (that benefits will be, for example, fewer than expected) and investment risk (that assets acquired by the investment of contributions will be insufficient to cover the expected earnings) shall be borne solely by the employee. When the employee has rendered service to the entity during a period, the entity will report in its accounts the contribution pay-able to a defined contribution plan.

In this case the program is characterized by the criteria in IAS 19 as "defined contribution plan" (IAS 19 Paragraph 7 Defined Contribution Plans). An "employee benefit" is covered by a defined contribution plan if the program meets the criteria:

- The legally and morally responsible entity for the provision is not the employer but other entities such as public or private entities funds, an insurance entity

- The employer-entity pays fixed contributions to the organization's benefit. The stability of contribution considered as:

- Stable financial amount

- Fixed rate usually in the immediate-term benefits

- The stability in the amounts and percentages is acceptable if they do not show high volatility over time. Pension funds and insurance entities adjust their rates and amounts received by the insured under the actuarial coverage of benefits they offer

- The employer-entity has no legal or constructive obligation or other significant additional amounts beyond the levy paid

When an employee has rendered service to an entity during a period, the entity shall recognize the contribution payable to a defined contribution plan in exchange for that service:
- As a liability (accrued expense), after deducting any contribution already paid. If the contribution already paid exceeds the contribution due for service before the balance sheet date, the entity shall recognize that excess as an asset (prepaid expense) to the extent that the prepayment will lead to, for example, a reduction in future payments or a cash refund

- As an expense, unless another Standard requires or permits the inclusion of the contribution in the cost of an asset (see, for example, IAS 2 Inventories and IAS 16 Property, Plant and Equipment)

\subsubsection{With the Assumption of Liability and Cost of Providing an "Employee Benefit" by the Entity but Without Immediate Future Cash Payment to the Employee}

Defined benefit plans are post-employment benefit plans other than defined contribution plans. Under defined benefit plans:

- The entity's obligation is to provide the agreed benefits to current and former employees

- Actuarial risk (that benefits will cost more than expected) and investment risk fall, in substance, on the entity. If actuarial or investment experience are worse than expected, the entity's obligation may be increased. In this case, the program is under IAS 19 known as "defined benefit plan (IAS 19 Paragraph 7 Defined Benefit Plans)

Based on these programs and to address the liability and expense that this entails providing the entity is obliged to take the following actions:

- Recognition of the debt for all staff to provide cover (employees and pensioners)

- Identification of all actuarial risks that supply involves

- Identify all the benefits of the property formed is created by the employer and employee contributions to cover the provision over time

- Write an actuarial study to determine the current obligation to provide coverage

- Recognition from the entity's current obligation on its books. Recognition is based on actuarial assumptions in two groups of factors:

- Consideration of demographic factors such as mortality, rates of retirements

- The financial factors such as discount rates, property development efficiency wages 
Based on these factors the present value of benefit to employees after subtracting the present value of the property of pension funds is calculated by the entity. From this actuarial liability by subtracting the employee and employer contributions may come out with actuarial deficit. This deficit should be recognized immediately as a liability and expense by the entity. But there is also the possibility when the value of the pension fund property has been changed significantly positively resulting actuarial surplus. In this case it has to be recognized by reducing the requirement for the entities. This obligation cannot turn to a claim because the assets do not belong to the employer but to the pension fund.

The appropriate accounting procedure by the entity for defined benefit plans involves the following steps:

1) Using actuarial techniques to make a reliable estimate of the amount of benefit that employees have earned in return for their service in the current and prior periods. This requires the entity to determine how much benefit is attributable to the current and prior periods (see paragraphs 6771, IAS 19) and to make estimates (actuarial assumptions) about demographic variables (such as employee turnover and mortality) and financial variables (such as future increases in salaries and medical costs) that will influence the cost of the benefit (see paragraphs 72-91, IAS 19)

2) Discounting that benefit using the Projected Unit Credit Method in order to determine the present value of the defined benefit obligation and the current service cost (see paragraphs 64-66, IAS 19)

3) Determining the fair value of any plan assets (see paragraphs 102-104, IAS 19)

4) Determining the total amount of actuarial gains and losses and the amount of those actuarial gains and losses to be recognized (see paragraphs 9295, IAS 19);

5) Where a plan has been introduced or changed, determining the resulting past service cost (see paragraphs 96-101, IAS 19)

6) Where a plan has been curtailed or settled, determining the resulting gain or loss (see paragraphs 109-115, IAS 19)

Where the entity has more than one defined benefit plan, the entity applies these procedures for each material plan separately

\section{EMPLOYEE BENEFITS", SIMILARI- TIES AND DIFFERENCES BETWEEN ACCOUNTING STANDARDS IN AC- COUNING REPORTING}

The authorities responsible for establishing the General Accepted Accounting Principles (GAAPs) are generally:

- The International Accounting Standards Board (IASB)

- The Financial Accounting Standards Board in the U.S. (FASB)

- The Accounting Standards Board in the U.S. (ASB)

- Other professional accounting bodies such as the American Institute of Certified Public Accountants (AICPA)

- The Consultative Committee of Accountancy Bodies (CCAB) in the U.K

- The International Federation of Accountants (IFAC)

- The Australian Society of Certified Public Accountants (ASCPA) together with the Australian Institute of Chartered Accountants in Australia (ICAA)

In addition, there are other jurisdictional bodies and national accounting authorities that also help to set ac-counting standards. These bodies are public or private or mixed but most of them are private organizations organized by Professionals of Accounting and Certified Public Auditors under governance approval mainly by the Securities and Exchange Commission (SEC). These standards are important for the effective functioning of the economy because decisions about resource allocation are based on credible, concise and understandable financial information.

The largest accounting standards' development bodies are those of the International Accounting Standards Board (IASB) and the respective directors of U.S. Financial Accounting Standards' Board (FASB). These organizations are private organizations organized by professionals and experts in accounting, auditors having received approval from the governments of the countries that implement them. Since 1973, the Financial Accounting Standards Board (FASB) has been the designated organization in the private sector for establishing standards of financial accounting that governs the preparation of financial reports by nongovernmental entities. These standards are officially recognized as authoritative by the Securities and Exchange Commission (SEC).

The IFRS Foundation is an independent, not-for-profit private sector organisation working in the public interest. In addition, as it has been mentioned above there are other jurisdictional bodies and national accounting 
authorities, private, governmental or combination of both, that also help to set accounting standards. The works of all these authorities have implications to motivate and to establish greater corporate governance and disclosure and to create globally accounting harmonization. The main differences between U.S. Accounting Standards and IFRS are provided in the following comparative Table 1 with respect to topic of "employee benefits".

Table 1. The main differences between U.S.A., ac-counting standards and IFRS

\begin{tabular}{ll}
\hline Topic & IFRSs \\
\hline Termination benefits & $\begin{array}{l}\text { No distinction between "special" and } \\
\text { other termination benefits. Termination } \\
\text { benefits recognized when the employer } \\
\text { is demonstrably committed to pay. }\end{array}$
\end{tabular}

\section{US GAAP}

Recognize special (one-time) termination benefits generally when they are communicated to employees unless employees will render service beyond a "minimum retention period", in which case the liability is recognized ratably over the future service period. Recognize contractual termination benefits when it is probable that employees will be entitled and the amount can be reasonably estimated. Recognize voluntary termination benefits when the employee accepts the offer

\section{Recognizing actuarial Permitted}

gains and losses

directly in equity

when they arise

Recycling in profit

or loss of actuarial

Not permitted

gains and losses

previously recognized in equity

Measurement of gain or loss on curtailment of a benefit plan

Timing of recognition of gains/losses on curtailment of a benefit plan

Recognition of past service cost related to benefits that have vested Presentation of past service cost Multi-employer plan that is a defined benefit plan

Limitation on recognition of pension assets

Recognised immediately

A curtailment gain or loss comprises (a) the change in the present value of the defined benefit obligation (b) any resulting change in fair value of the plan assets (c) a pro rata share of any related actuarial gains and losses, unrecognized transition amount and past service cost that had not previously been recognized Both curtailment gains and losses are recognized when the entity is demonstrably committed and a curtailment has been announced

Presented as an offset or increase to the defined benefit obligation

Should be ac-counted as a de-fined benefit plan if the required information is available. Otherwise as a defined contribution plan

Pension assets cannot be recognized in excess of the net total of unrecognized past service cost and actuarial losses plus the present value of benefits available from refunds or reduction of future contributions to the plan
Subsequently these amounts will be reclassified from other comprehensive income and recognized in profit or loss as components of net periodic benefit cost

Similar to IFRSs. However, some detailed differences may arise in respect of: Unrecognized actuarial gains and losses, unrecognized transition amount and past service costs

A curtailment loss is recognized when it is probable that a curtailment will occur and the effects are reasonably estimable. A curtailment gain is recognized when the relevant employees are terminated or the plan suspension or amendment is adopted, which could occur after the entity is demonstrably committed and a curtailment is announced

Generally amortized over the remaining service period or life expectancy

Presented within other comprehensive income with unrecognized actuarial gains and losses Accounted for as a defined contribution plan

No limitation on the amount that can be recognized 
Table 2. The recent differences between U.S.A., accounting standards and IFRS

\begin{tabular}{|c|c|}
\hline Topic & IAS 19 (Revisions through 2008) \\
\hline \multicolumn{2}{|l|}{ Defined benefit plans } \\
\hline $\begin{array}{l}\text { Basis for accounting } \\
\text { (for each material plan) }\end{array}$ & $\begin{array}{l}\text { Legal obligation under formal plan } \\
\text { or constructive obligation based } \\
\text { on informal practices }\end{array}$ \\
\hline Going concern & Presumptions that, absent evidence \\
\hline Concept & to the contrary, plan will continue \\
\hline \multicolumn{2}{|c|}{ Measurement of benefit obligation } \\
\hline Valuations & $\begin{array}{l}\text { Plan obligation and assets to be } \\
\text { determined as of each balance sheet } \\
\text { date; use of qualified actuary } \\
\text { encouraged, but not required }\end{array}$ \\
\hline Actuarial method & Projected unit credit \\
\hline Attribution & $\begin{array}{l}\text { Follow benefit formula unless } \\
\text { disproportionate share attributed to } \\
\text { later years of service; in that case, } \\
\text { benefits attributed ratably over } \\
\text { credited service period to full } \\
\text { eligibility date }\end{array}$ \\
\hline
\end{tabular}

FAS $87 / 88 / 106 / 132 R / 158$

Written plan or substantive commitment to provide greater benefits than defined by the written plan (based on past practice of increasing benefits), or past practice of paying benefits. [For FAS 106, ac-counting is based on the substantive plan- the plan as understood by participants, based on past practice and communications]

Presumptions that, absent evidence to the contrary, plan will continue

Plan obligations and assets to be deter-mined as of balance sheet date; nature of measurements generally requires use of qualified actuary

Projected unit credit

Follow benefit formula unless disproportionate share attributed to later years of service; in that case, benefits attributed ratably over credited service to date benefit is first fully vested. [Under FAS 106, benefits attributed ratably over service period (credited service period if benefit formula credits only service from date later than date of hire) to full eligibility date; for front-loaded plans, follow benefit formula. For a plan that provides employee benefits retiring on or after age 55 with 10 or more years of service, and the amount of the benefit is not increased with service beyond 10 years, FAS 106 attributes the benefits to service from date of hire to the date at which an employee has both attained age 55 and rendered 10 years of service, whereas IAS 19 attributes benefits to the first 10 years of service after age 45]

Assumptions

Discount rate

Rate of return on plan

Benefit increases

Financial statement recognition

Balance sheet asset, limits
Explicit approach; assumptions should be unbiased and mutually compatible; entity's assumptions Current rates of return on high-quality corporate bonds with maturities consistent with duration of benefit obligations; in countries with no deep market in such bonds, return on government bonds is used Based on current market expectations over life of the obligation Benefit increases required under terms of plan or pursuant to constructive obligation; changes in existing law or level of government benefits considered only if enacted or benefits change in predictable manner

Pension asset limited to: PV of economic benefits derived from surplus + unrecognized actuarial loss + unrecognized prior service cost; gain/loss and/or prior service cost recognition accelerated in some situations; if gains and losses are recognized outside $\mathrm{P} \& \mathrm{~L}$, change in limit on prepaid pension asset is also recognized outside P\&L. [Economic benefit from surplus refers to amounts available as an unconditional right to a refund (net of costs, including excise tax) or as a reduction in future contributions]
Explicit approach; each assumption should represent management's best estimate with respect to that assumption; internally consistent

Rate at which obligation could be effectively settled (ignores insurer's cost of assuming risk); generally, current rates of return on high-quality fixed income investments with maturities matching duration of benefit obligations

Based on expected long-term rates over life of the obligation

Benefit increases specified by plan, including employer's substantive commitment; changes in existing law or level of government benefits considered only if enacted; possible changes in negotiated benefits should not be anticipated

Balance sheet reflects asset equal to surplus of all overfunded plans, i.e., fair value of plan assets-PBO (or APBO); no limit on asset 
Table 2. Continue

\begin{tabular}{ll}
\hline Balance sheet liability & Balance sheet reflects accrued liability \\
\hline cumulative amount expensed- \\
cumulative amount funded); additional \\
liability may be recognized if contribution \\
to meet minimum funding requirement \\
would not be available as a refund or \\
reduction in future contributions
\end{tabular}

Balance sheet-other reduction in future contributions

Cost recognized

Gain/loss recognition

Prior ser-vice Cost recognition (i.e., Cost of benefit improvements

Negative prior service cost (i.e., negative cost of benefit reductions)

Expected return on plan

Valuation of assets

Settlements and Curtailments Definition of settlement

Measurement of settlement
Service cost + interest cost-expected return on plan assets $+/$-net loss or gain recognized $+/-$ prior service cost recognized $+/-$ curtailment and settlement effects. [Gain/loss may be recognized through $\mathrm{P} \& \mathrm{~L}$ or outside P\&L in Other Comprehensive income (OCI) (Statement of Recognized Income and Expense through 2008)] Immediate or delayed recognition; at a minimum, amortize unrecognized net gain or loss falling outside corridordefined as $10 \%$ of greater of DBO or FV of plan assets-over average remaining ser-vice period of active employees expected to receive benefits under the plan.

Immediately recognize prior service cost for vested participants, amortize portion attributable to non vested participants over their average remaining service to vesting date

Same as for cost of

benefit improvement

Based on current market expectations and fair value of assets; reflect actual contributions benefit payments

Fair value (market price).

Entity eliminates or discharges all further legal or constructive obligation for part or all benefits under the plan, for example, by a lump sum payment Change in remeasured benefit obligation and plan assets, plus any additional cost of settling obligation for affected participants, plus pro rata share (in proportion to change in DBO) of unrecognized net gain or loss and unrecognized prior service cost (unless another basis is more rational)
Balance sheet reflects liability equal to PBO (or APBO)-fair value of plan assets for all underfunded (or unfunded) plans

Accumulated other comprehensive income (AOCI) reflects gains/losses, prior service cost/credits and transition obligation/asset not yet recognized in net periodic cost, net of tax effects

Service cost + interest cost-expected return on plan assets $+/-$ net loss or gain recognized + /-prior service cost recognized + temporary deviation from plan (FAS 106 only) $+/-$ curtailment and settlement effects

Immediate or delayed recognition; at a minimum, amortize unrecognized net gain or loss falling outside corridordefined as $10 \%$ of greater of PBO or MRV of plan assetsover average remaining service period of active employees expected to receive benefits under the plan; if all or almost all plan participants are former employees, use their average remaining life expectancy; gain/loss not yet recognized in net periodic cost is included in AOCI. [The Defined Benefit Obligation ("DBO") under IAS 19 is equivalent to the ProJected Benefit Obligation ("PBO") under FAS 87. For FAS 106 purposes, the Accumulated Postretirement Benefit Obligation ("APBO") is used]

Amortize over active participants' average remaining service periods or period benefited, if shorter; if all or almost all participants are inactive, use their average remaining life expectancy; prior service cost not yet recognized in net periodic cost is included in AOCI. [Average remaining service to full eligibility date is used for FAS 106]

First reduce any unrecognized prior service cost from benefit improvement, amortize excess on same basis as benefit improvement; negative prior service cost not yet recognized in net periodic cost is included in AOCI Based on expected long-term rate of re-turn and Market Related Value ("MRV") of assets; reflect expected contribution and benefit payments. [Market-related value may be fair value or a calculated value that recognizes changes in fair value over not more than 5 years] Fair value (market price, less cost to sell if significant) for funded status; MRV for determining expected return on assets

Irrevocable action that relieves employer of primary responsibility for benefit obligation and eliminates significant risks with respect to obligation and assets used to settle

Change in re measured benefit obligation and plan assets plus pro rata share (in proportion to change in $\mathrm{PBO}$ ) of unrecognized net gain or loss and transition asset obligation and plan assets must be re measured using current assumptions before measuring settlement effect]. 
Table 2. Continue

\begin{tabular}{|c|c|c|}
\hline Recognition of & Recognize settlement gain or & Recognize settlement gain or loss when settlement occurs; \\
\hline Settlement & loss when settlement occurs & $\begin{array}{l}\text { if cost of all settlements for year is less than or equal to the } \\
\text { sum of the plan's service and interest cost, gain/loss } \\
\text { recognition is permit-ted, but not required policy must be } \\
\text { consistently applied) }\end{array}$ \\
\hline Definition of & $\begin{array}{l}\text { Commitment to significantly reduce } \\
\text { number of employees covered by plan } \\
\text { or amend DB plan so significant } \\
\text { portion of future service no longer } \\
\text { qualifies for benefits or qualifies only } \\
\text { for reduced benefits curtailment }\end{array}$ & $\begin{array}{l}\text { Event that significantly reduces employees' expected years } \\
\text { of future service or eliminates accrual of future defined } \\
\text { benefits for a significant number of employees }\end{array}$ \\
\hline $\begin{array}{l}\text { Measurement of } \\
\text { curtailment }\end{array}$ & $\begin{array}{l}\text { Effect of change in benefit obligation } \\
\text { and fair value of assets, plus pro rata } \\
\text { share (in proportion to change in } \\
\text { DBO) of unrecognized prior service } \\
\text { cost, net gain or loss (unless another } \\
\text { approach is more rational) }\end{array}$ & $\begin{array}{l}\text { Increase/decrease in benefit obligation in excess of } \\
\text { unrecognized gain (if increase) or loss (if decrease), plus } \\
\text { pro rata share (in proportion to reduction in participants' } \\
\text { future years of ser-vice) of unrecognized prior service cost } \\
\text { and transition obligation. [Service to full eligibility date is } \\
\text { used for plans accounted for under FAS 106] }\end{array}$ \\
\hline $\begin{array}{l}\text { Recognition of } \\
\text { curtailment }\end{array}$ & $\begin{array}{l}\text { Recognize curtailment gain or } \\
\text { loss when curtailment occurs }\end{array}$ & $\begin{array}{l}\text { Recognize curtailment loss when probable and reasonably } \\
\text { estimable, recognize curtailment gain when employees } \\
\text { terminate or plan amended }\end{array}$ \\
\hline
\end{tabular}

General

Benefit obligation

Plan assets

Funded status

Balance sheet

Cash flows

Cost

Assumptions

Historical information
Description of plan, including any informal practice used in measuring the DBO

Reconciliation of changes in benefit obligation

plans with $\mathrm{PBO}>$ fair value of plan assets Reconciliation of changes in fair value of plan assets

Funded status reconciliation
Employer contributions expected in next fiscal year

Net periodic cost, by component and where reported If gains/losses recognized in SORIE:

Current year recognition Net gain/loss

Effect of limit on prepaid asset

Cumulative gains/losses recognized through OCI (SORIE)

Key assumptions, e.g., discount rate, EROA, salary growth Basis for determining EROA, including effect of asset classes Assumed health care cost trend rates; sensitivity information Five-year history of: DBO

Plan assets

Funded status

Liability-related experience

gains /losses

Asset-related

experience gains/losses
Reconciliation of changes in benefit obligation

$\mathrm{ABO}$

$\mathrm{PBO}, \mathrm{ABO}$ and fair value of plan assets for plans with $\mathrm{ABO}$

$>$ fair value of as-sets; PBO and fair value of plan assets for

Reconciliation of changes in fair value of plan assets

Asset allocation

Asset investment strategy

Funded status

Balance sheet classification (current vs. noncurrent)

Amounts recognized on balance sheet, including amounts recognized in AOCI and effects of

additional mini-mum liability

Changes in AOCI due to deferred costs/income arising

during year (i.e., gains/losses and prior service cost/credit)

and amortizations during year

Employer contributions expected in next fiscal year

Benefits expected to be paid (each of next five years

$\& 5$-year period thereafter)

Net periodic cost, by component

Gain/loss recognition policy, if other than minimum

amortization required by "corridor" approach

Estimated amortizations for coming year

Prior service cost recognition policy

Key assumptions, e.g., discount rate, EROA, salary growth Basis for determining EROA

Assumed health care cost trends rates (initial, ultimate, pattern of change); sensitivity information 
Table 2. Continue

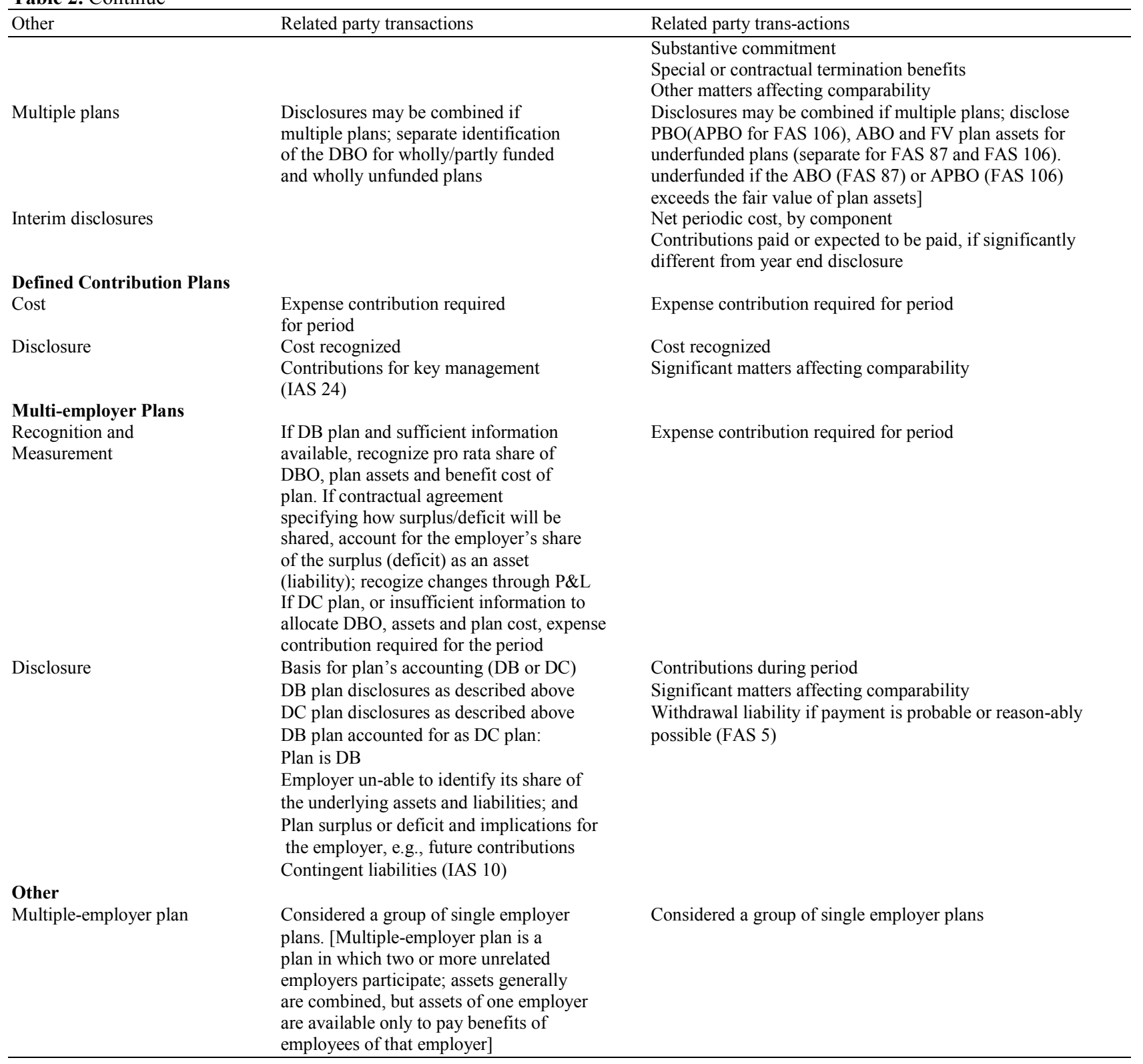

The recent differences between IAS 19 (Revisions through 2008) and FAS 87/88/106/132R/158 are presented in Table 2.

The latest changes-amendments are made to IFRS in the summer of 2011. In addition to other they focus largely in accounting estimates for settlements canceled or cut-curtailment "employee benefits" programs. This could be attributed to the recent financial crisis where the need to reduce entities working costs by cancellations or cuts-curtailments and programs of "employee benefits" were high. The following conclusions can be drawn from the comparative juxtaposition of accounting standards for retirement benefits that are moving in a phase of convergence rather than divergence. IFRS shows greater prudence by not allowing the emergence of surpluses in the financial statements and requires a faster recognition of these actuarial losses on benefit plans to employees. IFRS have also implied greater transparency by 
publishing the details of "employee benefits", by instituting screening for the presence of outside legal and moral or constructive obligations of entities to employees that should be quantified and then to appear in the financial statements of entities.

\section{THE IMPLEMENTATION OF IFRS: THE CASE OF GREECE}

\subsection{The Situation Before the Implementation of IFRS}

The General Collective Commitment Contract between employers-employees or separate entities contracts or provisions according to the certain law, or internal rules of undertaking is applicable in Greece for many years in the case where they provide higher benefits than the law for termination and retirement from work. The entities which cover "employee benefits" are retirement insurance funds with the largest being IKA-TEAM on primary and secondarysupplementary insurance funds. The terms and the conditions of employment are covered by the appropriate labor legislation.

In Greece before the implementation of IFRS, most entities in order to avoid the burdens of their financial statements were making provisions for compensation of personnel due to retirement, based on the opinion of the Government Legal Management Consulting Council $(205 / 1988)$ and article 10 of Law 2065/1992. This opinion essentially allows entities to make provisions for termination and retirement from employment only for those employees who had anticipated that they would leave job (termination or lay off) in the next financial year. Also, pension funds out of Social Security TEAM and especially those of the Greek banking sector have, legally or ethically-constructive, defined benefit plans.

\subsection{The Status of Transition to IFRS}

The accounting principles which are used and displayed in the financial statements of entities in Greece follow IFRS are described below. Actual data from published financial statements of the 20 biggest listed entities in the ASE (FTSE 20 index of ASE) have been used. The financial disclosures on the accounting policies, under which reproduce the formal notification financial statements following the identification of various issues relating to "employee benefits" according to IFRS have been also taking into consideration.
In Greece, there are defined benefit plans and defined contribution plans and the entities make the following disclosures for them. For defined contributions plans the entity pays a fixed, as appropriate, contribution amount to an independent body private or public pension or insurance fund. The entity has no further legal or constructive obligation to pay further contributions if the agency does not have the necessary assets to cover the benefits associated with service personnel in the current or past years. In a defined contribution plan, the entity shall pay contributions to insurance agencies, public or private law, on a mandatory or voluntary basis to insurance entities and special accounts. The obligation to pay is exhausted in this case. The contributions are recognized in staff costs by applying the principle of accruals. Any prepaid contributions are recognized as an asset if they are accompanied with either a cash refund or a reduction in future contributions.

The amount of provisions to cover the defined benefit plans' liabilities are functioned with the years of employment and the salary of employees and are guaranteed by the entity. The liability which is recognized in the financial statements is the present value of the accrued benefits minus the fair value of plan assets, taking into account any adjustments for actuarial scores (gains/losses) and costs for past services. The amount of liability is determined annually based on actuarial valuation prepared by an independent actuarial firm, using the Projected Unit Credit Method. This value is determined by discounting the estimated future cash flows at the rate applicable to investment grade credit rating, issued in a currency common to the one paid by the defined benefit and has a remaining term in line with the duration of the obligation.

The cumulative actuarial gains/losses arising from the discrepancy between estimates and experience and the change in actuarial assumptions used in the part exceeding $10 \%$ of the greater of the accrued liabilities and the fair value of plan assets, amortized over a period equal to the average remaining working live of employees. The cost of past service years is recognized immediately in profit or loss, unless the changes in the supply base depend on the retention of employees in work for a specified period of time. In the second case, the service cost is amortized in previous years following the linear method during this period. 
With the initial condition, Greek GAAPs, applied for measurement of "employee benefits" obligations by entities in Greece especially for retirement and termination benefits, significantly underestimate the corresponding provisions on their accounting statements. The adjustments which are made for recognition of "employee benefits" accumulated provisions after the implementation of IFRS by the entities of FTSE 20 are presented in Table 3. As it is observed the implementation of IFRS has forced entities to make additional significant provisions for "employee benefits", until then, with the combined force of legislation, transparency to the financial statements on this issue was very limited. A crucial characteristic which is of great importance is the fact that the major adjustments made to credit institutions established and operating in Greece. The same characteristic exists but to a smaller degree true for the other entities in the index with the exception of relatively small adjustments by OTE and Titan.

Figure 1 shows the part of adjustments under IFRS in comparison with provisions already made for "employee benefits" under Greek GAAPs. The total pie presents the necessary provisions under IFRS.

At the same time the adjustments raised the problem for the coverage of "employee benefits" by the Greek Banks in the index. The breakdown of provisions for "employee benefits" of listed companies of FTSE 20 index of ASE is shown in Fig. 2.

The Greek Government in order to bypass the problem avoids to enforce measures to imply financial and actuarial methods for the entities to calculate the amount of "employee benefits" obligation per bank (extremely huge burden) and creates a new insurance entity which is essentially the conversion of pension funds from defined benefits plans with legal or constructive obligation against bank employees to a common defined contribution plans.

Thus, the supplementary pension fund for employees of the National Bank of Greece, the TAPILTAT, the TEA-PETE and other banks' pension funds were abandoned and the bank employees are included in the new defined contribution plan ETAT. By Legal Decision of the Greek High Court 2199/2010 the issue was resolved as well as other problems related to the New Common Fund for Banks. As it is stated: "Under provisions of Law 3371/2005 the legislature permissibly following the Article 22, paragraph 5th of Constitution Law, chose the organizational form of a new entity under public law for compulsory social insurance of bank employees. These provisions do not contravene Article 12 of Constitution Law, because the existing insured under a mutual fund ETAT necessarily true, but the existed funds are either dissolved or removed property.

Table 3. Provisions for "Employee benefits" at IFRS Transition Period (FTSE 20)

\begin{tabular}{|c|c|c|c|c|}
\hline Listed Companies (FTSE 20) & Kind of business & Greek GAAP & IFRS Adjustments & IFRS \\
\hline Alpha $\beta \alpha v \kappa$ & Bank & 8.319 & 548.95 & 557.269 \\
\hline COCA-COLA 3E & Bottling, soft drinks & 21.9 & 47.5 & 69.4 \\
\hline Urobank EFG & Bank & - & 50 & 50 \\
\hline Jumbo S.A & Commerce & - & 1.074 & 1.074 \\
\hline Marfin investment group & Holding company & 770 & - & 770 \\
\hline Marfin popular bank & Bank & 168.498 & - & 168.498 \\
\hline Bio $\chi \alpha$ lko S.A & Metallurgy, industry & 1.79 & 16.574 & 18.364 \\
\hline DEH & Electric power & 289.129 & - & 289.129 \\
\hline NBG (KO) & Bank & - & 225.331 & 225.331 \\
\hline Ellaktor (KO) & Metallurgy, industry & 279 & 4.183 & 4.462 \\
\hline Elpe (KO) & Oil company & 77.593 & 31.118 & 108.711 \\
\hline $\mathrm{K} \alpha \varepsilon(\mathrm{KO})$ & Commerce & - & - & - \\
\hline Bank of cyprous & Bank & 2.462 & - & 2.462 \\
\hline Motor oil (KO) & Oil company & 3.122 & 41.889 & 45.011 \\
\hline Mytilineos S.A & Holding, metallurgy, industry & 2.416 & 30.07 & 32.486 \\
\hline OPAP S.A & Bookmaker company & 20.816 & 2.675 & 23.491 \\
\hline OTE & telecommunications & 486.1 & 91.9 & 578 \\
\hline Piraeus bank & Bank & 4.738 & 145.485 & 150.223 \\
\hline Hellenic postbank & Bank & 693 & 15.912 & 16.605 \\
\hline TITAN S.A & Cement & 24.643 & 14.999 & 39.642 \\
\hline \multicolumn{2}{|c|}{ Total amount of provisions for employee benefits } & 1.113 .268 & 1.267 .660 & 2.380 .928 \\
\hline
\end{tabular}

Source: Entities websites published financial statements of listed entities (FTSE 20 index) 

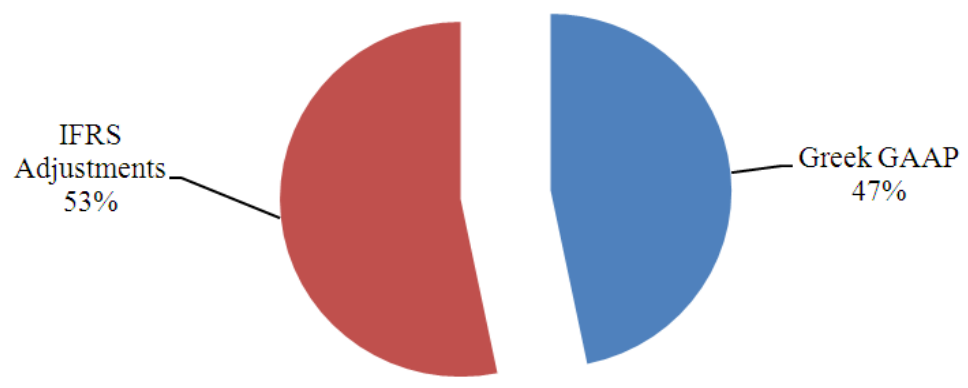

Fig. 1. IFRS provisions for "employee benefits

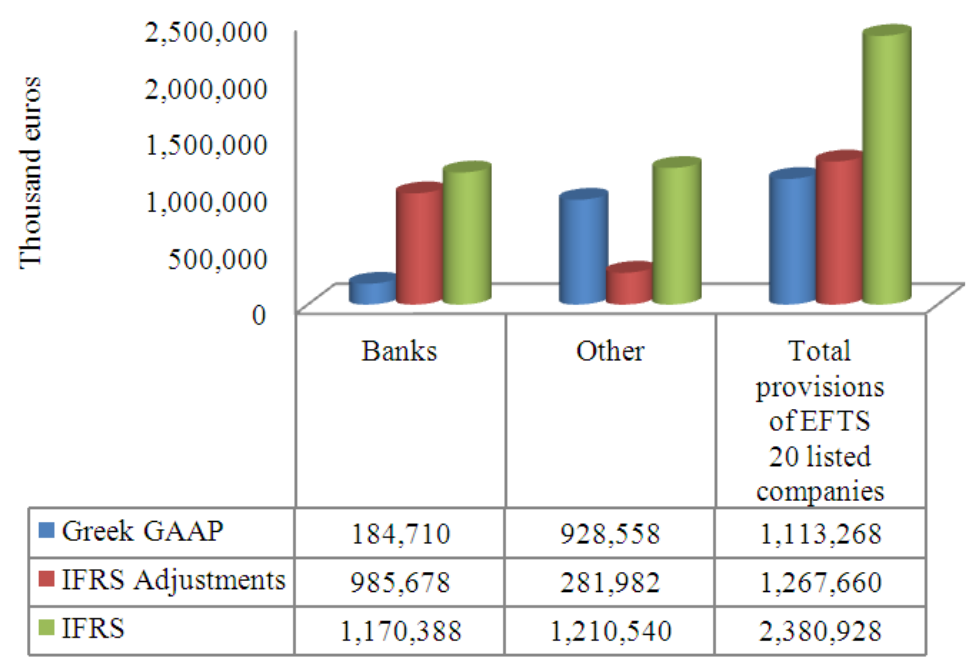

Fig. 2. Provisions for employee benefits of listed companies of FTSE 20 index ASE

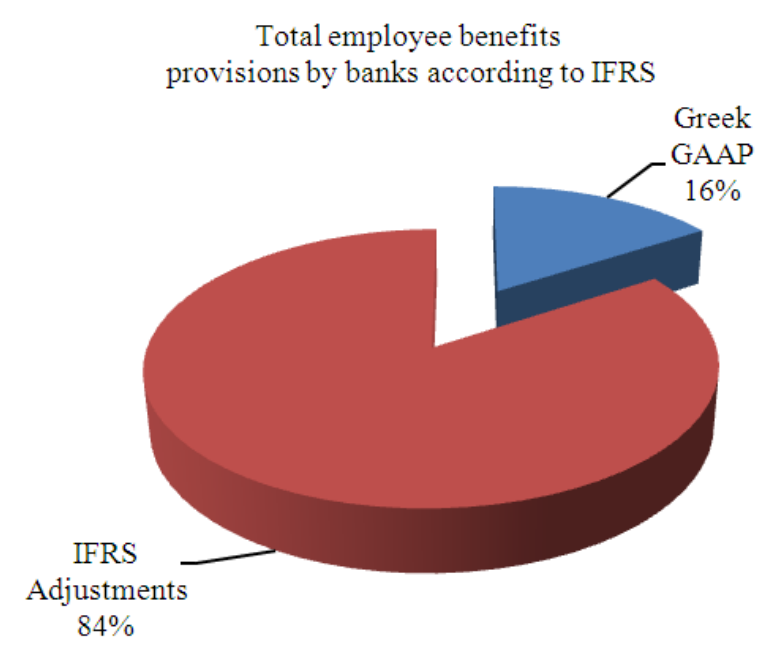

Fig. 3. IFRS additional provisions for the banking industry

Under these circumstances, neither the principle of a protected confidence nor the principle of proportionality violated. Moreover, such rules do not conflict with the contractual freedom, since not the case here overcoming the extreme limits of the concept of public interest or the principle of proportionality. Finally, there is no question of violation of the Constitution and rules of international law for the protection of property and collective autonomy".

Another notable action before the implementation of IFRS was to avoid publication of separate accounts per bank by the Board of TAPILTAT (a multi-employer pension fund), thus, from a multi-employer defined benefit plan for the banks participating in the fund was essentially a defined contribution plan without being picked up beyond the capital paid in any other provision.

In order to apply IFRS in the country defined contribution plans became almost all employee benefit plans and actuarial estimates were converted into economic estimates to determine their contribution to the new defined contribution plan. The respective amounts based on actuarial estimation of liabilities was substantially larger, with the actuarial status of uncapped not been announced. 
Figure 3 shows the final impact of adjustments under the IFRS for the Greek Banks in the index which is significant high despite the changes on the legislation of the Funds, which have been mentioned above.

However, the application of the IFRS in the country forced entities to recognize on their financial statements significantly higher provisions for "employee benefits".

\section{CONCLUSION}

The framework of international practice on "employee benefits" displays, sphericity and completeness and it has been monitored and completed over time. The Inter-national Accounting Standards are forcing entities to comprehensively address issues related to "employee benefits". Since they are involved only in the technical accounting treatment proposed but with scientific precision how the obligations of the entity to its employees for all benefits are being calculated correctly requiring an immediate recognition of employees' obligations on their financial statements by correcting their results.

The differences between accounting standards and the timeline of adjustments-amendments on them lead to a convergence rather than divergence among them. IFRS compared to other accounting standards, show greater prudence by not allowing the emergence of surpluses in the financial statements and require faster recognition of these actuarial losses. Also, they show greater transparency over other standards, requiring publication of de-tails of "employee benefits" while instituting screening for the presence of outside legal and moral obligations or presumed entities to employees that should be quantified appearing on the entities' financial statements.

The recent IFRS adjustments-amendments in the summer of 2011 in addition to some others in the past focus largely on forecasts of accounting settlements canceled or cut-curtail "employee benefits" programs. This can be attributed to the recent financial crisis where the need to reduce entities' working costs has lead to cancellations or cut-curtail programs of "employee benefits", resulting in adjustments and accounting standards.

Another issue that arises during financial crises is the use of discount rates from high-interest rate bonds, like government bonds in the case of Greece, to discount actuarial liabilities. With high yields on Greek bonds the appearance of a financial crisis would resulted to a dramatic reduction of the present value of liabilities owed to employees since they are used as instruments of high credit capacity and this is an issue that needed attention. On the other hand the haircut of Greek bonds has dramatically reduced the property of pension funds increasing the actuarial lose.
In order to adapt IFRS Greece has transposed almost all defined "employee benefit plans" to defined contribution plans while actuarial estimations were converted into economic estimations to determine their contribution to the new defined contribution plans. On the other hand the application of IFRS in the country led to the recognition by the entities clearly larger provisions -liabilities for the "employee benefits" by putting the matter in the proper perspective.

\section{REFERENCES}

Reiter, S.A. and T. Omer, 1992. A critical perspective on pension accounting, pension research and pension terminations. Critical Perspectives Account., 3: 6185. DOI: 10.1016/1045-2354(92)90015-J

Barlev, B. and R.J. Haddad, 2003. Fair value accounting and the management of the firm. Critical Perspectives Account., 14: 383-415. DOI: 10.1016/S1045-2354(02)00139-9

Gerald, G.L., 1994. The projected unit credit method with benefits apportioned by interest adjusted salaries. Trans. Society Actuaries, 24: 193-226.

Hallman, V.G. and J.S. Rosenbloom, 1986. Employee Benefit Planning. 1st Edn., Englewood Cliffs, Prentice-Hall.

Jean-François, G., 2009. Potential actuarial contributions to the redesign of employers' accounting standards for "employee benefit plans (IAS 19/SFAS 87). Proceedings of the Chairman of the IAS 19 Workgroup of the Académie des Sciences et Techniques Computables et Financières, pp: 1-16.

Lange, D.P. and B. Howieson, 2006. International Accounting Standards Setting and U.S. Exceptionalism. Critical Perspectives Account., 17: 1007-1032. DOI: 10.1016/j.cpa.2005.08.011

Marsh, B. and H.B. Kleiner, 2004. An overview of trends in employee benefits programmes. Manage. Res. News, 27: 1-8. DOI: $10.1108 / 01409170410784400$

Pegg, T., 2009. Creating engagement through employee benefits. Strategic HR Rev., 8: 5-12. DOI: 10.1108/14754390910937521

Severinson, C., 2010. The New IAS 19 Exposure Draft", OECD Working Papers on Finance, Insurance and Private Pensions, No. 5, OECD Publishing.

Sutton, V., 1993. Harmonization of international accounting standards: Is it possible? J. Accounting Education, 11: 177-84.

Tarca, A., 2004. International convergence of accounting practices: Choosing between IAS and US GAAP. J. Int. Finan. Manage. Account., 15: 60-91. DOI: 10.2139/ssrn.318319 